\title{
Evaluation of Occurrence and Resolution of Conflicts in and around Forest Reserves in Ondo State, Nigeria
}

\author{
Adedayo, A. G. \\ Department of Forestry and Wood Technology, Federal University of Technology, Akure, Ondo State, Nigeria \\ *Corresponding Author: Adedayo, A. G., Department of Forestry and Wood Technology, Federal \\ University of Technology, Akure, Ondo State, Nigeria
}

\begin{abstract}
Conflicts occur in forest reserves in Nigeria due to the multiple uses of the forest. This paper therefore seeks to identify types of conflicts that have occurred in forest reserves of Ondo state, Nigeria, examine causes of conflicts and examine how conflicts are resolved. Four forest reserves were selected based on the ecological zones in the study area. One forest reserve in mangrove forest and derived savanna and two forest reserves in the lowland rain forest. Four forest communities were randomly selected from each of the sampled forest reserves. Semi- structured questionnaire were used to obtain information from twenty randomly selected household heads in each sampled forest community. In addition 15 forestry personnel from each sampled forest reserve were randomly selected. The result of the study showed that types of conflicts that have occurred in forest reserves of the study area include disputes between forest communities, disputes between foresters and forest concessionaires and disputes between herdsmen and farmers. Causes of conflicts include boundary encroachment, herdsmen invasion and illegal felling. Chi-square test shows that the involvement of foresters in conflict resolution is dependent on their working experience. Conflicts are resolved through meetings between forestry officials, community leaders and the contending parties.
\end{abstract}

Keywords: Conflict Occurrence, Conflict Resolution, Forest reserves, Forest management

\section{INTRODUCTION}

Peace is a necessary ingredient for development. This is because it is in an atmosphere of peace that economic activities that can bring development thrive very well. However achieving peace seems to be a herculean tasks. This is especially so in Africa where achieving peace seems to be a ceaseless run after a mirage. As such occurrence of conflict is a common phenomenon in Africa. Schmid [1] defined conflict as the situation where two or more parties perceive their interests as incompatible and express hostile attitudes or pursue their interest through actions that damage other parties. The reason for so many conflicts in Africa is unconnected with the occurrence of fighting's and quarrels over access and control over resources such as water, land, forests and minerals. As noted by Shah [2] there have been over 9 million refugees and internally displaced people from conflicts in Africa. $\mathrm{He}$ noted further that hundreds and thousands of people have been slaughtered from a number of conflicts and civil wars in Africa. The occurrence of conflicts over access and use of forest resources in Nigeria seems to be more worrisome due to the frequency of occurrence and the negative impact it is having on the welfare and good living of the people. Walker and Daniels [3] noted that conflict in the forest sector is common and can range from wars of words to serious acts of violence. It most often follows disputes over rights to land and resources but can also arise over conservation priorities, pollution, and access to benefits from the sector. The reason for this is due to the fact that many people in Nigeria and all over Africa need forests and forest products for diverse needs. Most especially many people need the forest to support their livelihood. It is in the process of access or use of the forest that conflicts arise. As noted by Agbeja and Otesile [4] societies everywhere compete for natural resources to enhance their livelihoods.. It is in the process of competing for these natural resources like the forests that conflict occurs. It is disheartening to note that the occurrence of conflicts over natural resources especially the forest has assumed a frightening dimension in recent years.. This is because many youths now constitute themselves into militant groups preventing uniform field staff from performing their duties. As noted by Adetula [5] in recent years another dimension has been added to the occurrence of criminal activities in forest reserves in Ondo state. He noted that youngsters 
constituted themselves into militant groups to resist or even harass uniform field staff whose mandate is to protect the forest estate. He noted further that cases of death have been recorded in the hands of these gangsters. It is sad to note that despite the increasing occurrence of conflicts over the use of the forest in Nigeria there has been little or no documentation of these conflicts and attempts aimed at forestalling future occurrence has been minimal. As noted by Agbeja and Otesile [4] in spite of the numerous incessant conflicts that occur among forest land users in Ogun State forest reserves, there is no detailed documentary evidence on the causes of these conflicts. As such there has been no serious attempt at resolving conflicting issues among the differing groups. It is therefore not a surprise that the occurrence of conflicts seems to be on the increase not only in Ogun State but all over the country. It is in view of this that this paper seeks to identify types of conflicts that have occurred in forest reserves of Ondo state, Nigeria, to examine causes of conflicts in forest reserves in the study area as well as examine how these conflicts are resolved.

\section{CONCEPT OF CONFLICT OCCURRENCE AND CONFLICT RESOLUTION IN FOREST MANAGEMENT}

\subsection{Conflict Occurrence in Forest Management}

Conflicts occur in forest management and utilizations due to the multiple functions and use of the forest. Much importantly conflicts occur because diverse group of people with differing values and use of the forests have interest in the forest. The use and management of forest resources have been a source of tension between different actors' user groups. Though the reservation of the forest was intended to preserve the forest and its resources for the good of all, it was met with stiff resistance from the local people. Enabor [6] noted that little was achieved in the reservation of $25 \%$ of the country's land area as forest reserve due to stiff resistance of local community dwellers who rightly establish their claim to the land. Forest conflicts are inevitable as long as there are competing rights, claims, interests, values and power struggles that are enmeshed in complex institutions and multiple legal systems of land tenure ship [7].Therefore in the cause of striking a balance between needs and utilization, a tense relationship between the community dwellers and the managing authorities has been created hence subjecting the reserves to the greatest varieties of land use pressures and resourceuse conflicts.

Studies have shown that causes of land use conflicts include land hunger, poverty, demand for land for farming, unsustainable farming practices, unfair benefit sharing, ownership rights and control, inappropriate policies, poor management, weak cross-sector harmonization and high population growth [8 and 9]. Agbeja and Otesile [5] noted that one of the major cause of conflicts between agricultural and forestry land uses in Ogun State, Nigeria is land hunger. They noted further that scarcity of land which exists as a result of increasing demand for land outside forest reserves to accommodate development; make farmers without secure rights of access to land see the reserves as a favourable alternative in view of ease of access.

It is important to also note that unclear or differing interpretations or violations of rights and tenure are invariably at the root of conflicts. Such conflicts normally arise because particular user groups are excluded from participating or sharing in the benefits of forest management. Conflicts occur if there are contradictions between local and introduced management systems, misunderstandings and lack of information about policy and program objectives, contradictions or lack of clarity in laws and policies, inequity in resource distribution, or poor policy and program implementation.

More so, It has been found that the imposing something on the local community is discouraging. Hence, when people are not in support of the program me or in support of the things government impose on them it may lead to disagreement (conflict). Government's efforts at protecting forests are undermined by the fact that government has failed in its responsibility of providing jobs for the teeming youths. As such government forest protection laws has failed when faced with the population of the unemployed who need forest resources to survive. Many job seekers including farmers, lumbermen and hunters moved into the forest to cultivate it or cut trees despite government's claim of justification of ownership of the forest thereby resulting into conflicts between these people and government officials (Foresters). More so, the indigenous landowners still claimed ownership of the land they sold by demanding for the payment of annual land rent (Isakole), from the users of the land even though the land is supposed to have been sold. This always results into conflicts even when government tries to intervene. The believe of the indigenous people is that government has no right in their land affairs. Examples of common forest conflicts include disputes between forest communities over village boundaries, disputes between forest concessionaires and local communities over access to 
forest products, decision making, and benefit sharing. Those conflicts tend to be localized and may persist for long periods.

\subsection{Conflict Resolution in Forest Management}

One of the principal aims of forest management is to ensure judicious management of forest resources to ensure continuous availability of forest resources for the use of the people. However judicious management of forest resources is only possible under a peaceful atmosphere. As such when conflicts arise in forest reserves it is better to resolve as fast as possible in order to allow for continuous flow of benefits from the forest to the people. Bishnu [10] noted that forest resources were the most contentious issue, given their multiple uses. He noted further that the same forests are used by traders to collect medicinal herbs and other non-timber forest products, by local communities to collect wood for construction of buildings and bridges, and by local elites for political and economic gain. This often led to severe conflicts among users and within the community. Woolnough et al [11] noted that conflict can also lead to inequitable distribution of benefits, disputes over land rights and access, and a lack of engagement with the forest management process. It is estimated that between 1970 and 2008, $29 \%$ to $56 \%$ of all civil conflict globally involved natural resources including forests.

Forest reserves have become sites for conflicts in recent times not only in Nigeria but in many other countries. FAO [12] noted that conflicts are common in forest management. They exist in practically all countries. FAO [12] noted further that the reason behind forest conflicts is inherent in forest management being multi-objective and therefore with many stakeholders (local forest users, different government agencies in-and outside the forest administration, civil society, and the private sector) often having competing interests. As such forest reserves have become site for serious conflicts due to increasing competition for the resources of the forests. Woolnough et al [11] noted that forests as a valuable resource have frequently been the spark that ignites conflict among multiple stakeholders having divergent priorities for the same landscape. When one group whether inadvertently or deliberately withholds access to a forest resource or to the decision-making process from another user group. Zachrisson and Lindah [13] also noted that increasing competition over the world's forest resources will likely aggravate conflict. It is however important that conflicts are resolved quickly when they occur than to be left to linger on. This is because conflict will disrupt the smooth management of the forest. Rahim [14] noted that conflict resolution involves the reduction, elimination, or termination of all forms and types of conflict. He noted further that in practice, when people talk about conflict resolution they tend to use terms like negotiation, bargaining, mediation, or arbitration. Conflict resolution is different from conflict management. Conflict management involves designing effective macro-level strategies to minimize the dysfunctions of conflict and enhancing the constructive functions of conflict [14].

\section{MeThOdOLOGY}

\subsection{The Study Area}

Ondo State lies between latitude $5^{\circ} 45^{1}$ and $8^{\circ} 15^{1} \mathrm{~N}$ and longitude $4^{\circ} 25^{1}$ and $6^{\circ} 5^{1} \mathrm{E}$. Its land area is about 15,823 square kilometer [5]. Edo and Delta states bound Ondo on the east, on the west by Ogun and Osun states, on the North by Ekiti and Kogi states and to the South by the Bight of Benin and the Atlantic Ocean (fig.1).

\subsubsection{Vegetation}

Based on Keays [15] classification of Nigerian vegetation, three distinct vegetation belts can be identified in the state. These are mangrove in the south, lowland rain forest in the central and derived savanna in the north. Mangrove forest is dominated by the mangrove tree species. These are Rhizophora racemosa, Rhizophora mangle, and Rhizophora harrisonii. The lowland rainforest consists of tree species such as Milicia exelsa, Antiaris africana, Terminalia superba and Triplochiton scleroxylon. The derived savanna consists of tree species like Anogeissus leiocarpus, Nauclea latifolia, Dialum guineense, and Vitex doniana.

\subsection{Data Collection}

Four forest reserves were purposively selected based on the ecological zones in the study area. One forest reserve was selected in the mangrove forest, two forest reserves in the lowland rain forest and one forest reserve in the derived savanna. Four forest communities were randomly selected from each of the sampled forest reserves to make a total of sixteen forest communities. Pre tested and validated 
Evaluation of Occurrence and Resolution of Conflicts in and around Forest Reserves in Ondo State, Nigeria

semi- structure questionnaire was used to obtain information from twenty randomly selected household heads in each sampled forest community to make a total of three hundred and twenty respondents in the study area. In addition 10 forestry personnel from each forest reserve were randomly selected to make a total of 40 forestry personnel in the study area. In addition interview schedule was used to collect information from two key informants in each of the sampled community.

Table1. List of sampled communities in the study area and their coordinates

\begin{tabular}{|c|c|c|c|c|}
\hline & Forest Reserve & Community & Latitude & Longitude \\
\hline Ileoluji/Okeigbo & Akure Fr & Obada & 7.276494 & 5.026261 \\
\hline & & Kolawole & 7.268917 & 5.012228 \\
\hline & & Kajola & 7.250528 & 5.066206 \\
\hline Akoko South West & Oyinmo & Ago Obe & 7.234465 & 5.06274 \\
\hline & & Ago Ajaye & 7.347459 & 5.695593 \\
\hline & & Ose & 7.318262 & 5.672617 \\
\hline & & Owalusi & 7.38904 & 5.657052 \\
\hline Ilaje Ese Odo & Eba Island & Osobu & 7.3863 & 5.638757 \\
\hline & & Atijere & 6.413475 & 4.526023 \\
\hline & & Ebule Ipara & 6.26282 & 4.683436 \\
\hline & Olokata & 6.320195 & 4.501952 \\
\hline & Ipele Ido Ani & Agerige & 6.333106 & 4.61612 \\
\hline & & Gbegburu & 7.214316 & 5.792742 \\
\hline & & Alabase & 7.214693 & 5.792913 \\
\hline & & Wese Olorunfunmi & 7.1780521 & 5.754271 \\
\hline & & Wese Caterpillar & 7.174525 & 5.741709 \\
\hline
\end{tabular}

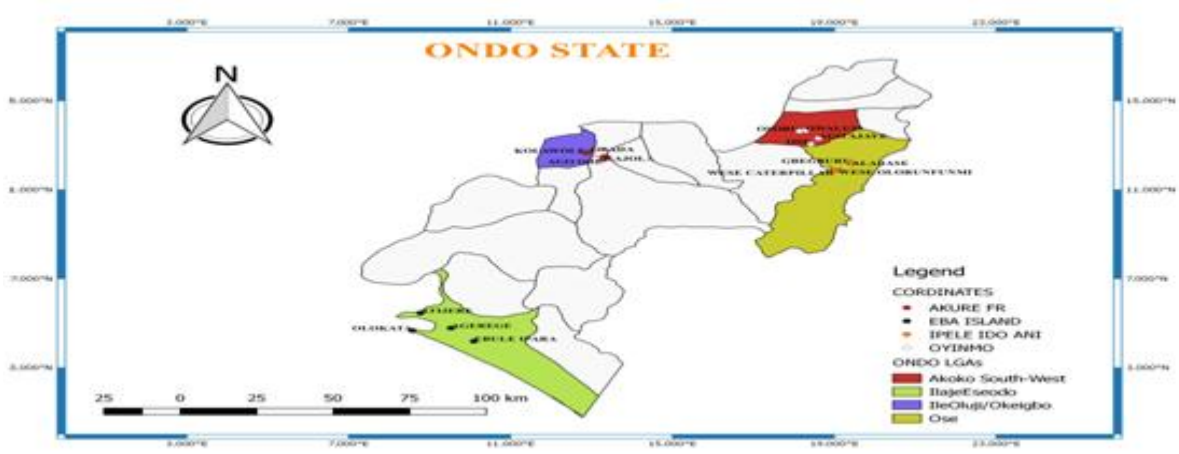

Figure: Map of Ondo State Showing sampled forest reserves

Table2. Questionnaire administration of household heads in sampled communities in the study area

\begin{tabular}{|c|c|c|c|}
\hline Villages & $\begin{array}{c}\text { Number of } \\
\text { questionnaire } \\
\text { Administered }\end{array}$ & $\begin{array}{c}\text { Number of } \\
\text { questionnaire Returned }\end{array}$ & $\begin{array}{c}\text { Percentage of } \\
\text { questionnaire } \\
\text { returned \% }\end{array}$ \\
\hline Ago obe & 20 & 20 & 100 \\
\hline Kajola & 20 & 20 & 100 \\
\hline Kolawole & 20 & 20 & 100 \\
\hline Obada & 20 & 20 & 100 \\
\hline Ago ajaye & 20 & 20 & 100 \\
\hline Ose & 20 & 20 & 100 \\
\hline Owalusi & 20 & 20 & 100 \\
\hline Osobu & 20 & 20 & 100 \\
\hline Atijere & 20 & 20 & 100 \\
\hline Ebule ipara & 20 & 18 & 90 \\
\hline Agerige & 20 & 19 & 95 \\
\hline Olokata & 20 & 20 & 100 \\
\hline Gbegburu & 20 & 20 & 100 \\
\hline Alabase & 20 & 20 & 100 \\
\hline Wese olorunfunmi & 20 & 20 & 100 \\
\hline Wese caterpillar & 20 & 20 & 100 \\
\hline
\end{tabular}


Evaluation of Occurrence and Resolution of Conflicts in and around Forest Reserves in Ondo State, Nigeria

Table3. Questionnaire administration of forestry personnel in the study area

\begin{tabular}{|c|c|c|c|}
\hline Forest reserves & $\begin{array}{c}\text { Number of } \\
\text { questionnaire } \\
\text { Administered }\end{array}$ & $\begin{array}{c}\text { Number of } \\
\text { questionnaire } \\
\text { Returned }\end{array}$ & $\begin{array}{c}\text { Percentage of questionnaire } \\
\text { returned \% }\end{array}$ \\
\hline Akure forest reserve & 15 & 10 & 67 \\
\hline $\begin{array}{c}\text { Oyinmo forest } \\
\text { reserve }\end{array}$ & 15 & 10 & 67 \\
\hline $\begin{array}{c}\text { Eba Island forest } \\
\text { reserve }\end{array}$ & 15 & 10 & 67 \\
\hline $\begin{array}{c}\text { Ipele Ido Ani forest } \\
\text { reserve }\end{array}$ & 15 & 10 & 67 \\
\hline
\end{tabular}

\subsubsection{Data Analysis}

The data was analyzed using simple descriptive statistics. This is informing of frequency and percentage distribution Tables. In addition chi-square test was used to test stated hypotheses.

\subsubsection{Research Hypothesis}

- Ho- There is no significant association between educational qualification of forest community dwellers and their involvement in causing conflicts in forest reserves in the study area.

- Ho - Involvement of forest community dwellers in causing conflicts in forest reserves of the study area is independent of their economic class.

- There is no significant association between the age of forest community dwellers and their involvement in causing conflict in forest reserves of the study area.

- Ho- Involvement of foresters in conflict resolution in forest reserves of the study area is independent of their working experience in the study area.

\section{RESULTS AND DISCUSSION}

\subsection{Socio- Economic Characteristics of the Respondents}

Table 4 shows the socioeconomic characteristics of respondents (forest community dwellers) in the study area. An average of $22 \%$ of the respondents had no formal education in the study area.37.8\% of the respondents on the average had only primary education in the study area.34\% of the respondents in the study area had secondary education while only $6.8 \%$ of the respondents had tertiary education in the study area. This shows that forest community dwellers are still lacking behind in terms of education. Majority of the people either have no formal education or had only primary education.

Ninety four percent of the respondents in the study area are above 30 years (Table 40. This shows majority of the respondents are matured. Their responses to the questions asked them can therefore be relied upon. Table 4 further shows that majority of the respondents in the study area belong to the low economic class. An average of $64.5 \%$ of the respondents in the study area is in the low economic class. These are the poor people with low income and with little or no asset. 35\% of the respondents are in the middle economic class while only $1 \%$ are in the high economic class. This shows that the level of poverty in forest communities is high as majority of the people belong to the low economic class.

Table4. Socio-economic characteristics of respondents in the study area (Forest Community Dwellers)

\begin{tabular}{|c|c|c|c|c|c|c|c|c|}
\hline \multirow[t]{3}{*}{ Socio-economic characteristics } & \multirow{2}{*}{\multicolumn{2}{|c|}{$\begin{array}{l}\text { Akure forest } \\
\text { reserve }\end{array}$}} & \multirow{2}{*}{\multicolumn{2}{|c|}{$\begin{array}{l}\text { Oyinmo forest } \\
\text { reserve }\end{array}$}} & \multicolumn{2}{|c|}{ Eba Island } & \multirow{2}{*}{\multicolumn{2}{|c|}{$\begin{array}{l}\text { Ipele/ Ido-ani } \\
\text { Forest reserve }\end{array}$}} \\
\hline & & & & & $\mathrm{N}$ & $\%$ & & \\
\hline & $\mathrm{N}$ & $\%$ & $\mathrm{~N}$ & $\%$ & & & $\mathrm{~N}$ & $\%$ \\
\hline \multicolumn{9}{|l|}{ Educational qualification } \\
\hline No formal education & 14 & 18 & 16 & 20 & 21 & 26 & 19 & 24 \\
\hline Primary education & 29 & 36 & 31 & 39 & 30 & 38 & 30 & 38 \\
\hline Secondary education & 30 & 38 & 28 & 35 & 26 & 32 & 25 & 31 \\
\hline Tertiary education & 7 & 9 & 5 & 6 & 3 & 4 & 6 & 8 \\
\hline \multicolumn{9}{|l|}{ Age of respondents } \\
\hline$<30$ years & 2 & 3 & 3 & 4 & 7 & 9 & 6 & 8 \\
\hline $30-40$ years & 23 & 29 & 26 & 32 & 20 & 25 & 14 & 18 \\
\hline
\end{tabular}


Evaluation of Occurrence and Resolution of Conflicts in and around Forest Reserves in Ondo State, Nigeria

\begin{tabular}{|c|ccc|cc|cc|cc|}
\hline $40-50$ years & 25 & 31 & 30 & 38 & 26 & 32 & 32 & 40 \\
$50-60$ years & 21 & 26 & 18 & 23 & 23 & 29 & 20 & 25 \\
Above 60 years & 9 & 11 & 3 & 4 & 4 & 5 & 8 & 10 \\
\hline Economic Class of & & & & & & & & \\
respondents & 48 & 60 & 52 & 65 & 56 & 70 & 50 & 63 \\
Low economic class & 30 & 38 & 28 & 35 & 23 & 29 & 30 & 38 \\
Middle economic class & 2 & 3 & & 0 & 0 & 1 & 1 & 0 & 0 \\
High economic class & & & & & & & & & \\
\hline
\end{tabular}

Table5. Socio-economic characteristics of respondents in the study area (Forestry Personnel)

\begin{tabular}{|c|cc|cc|cc|cc|}
\hline Length of service & 1 & 10 & 2 & 20 & 0 & 0 & 0 & 0 \\
$<5$ years & 3 & 30 & 1 & 10 & 3 & 30 & 2 & 20 \\
$5-10$ years & 1 & 10 & 3 & 30 & 1 & 10 & 2 & 20 \\
$11-15$ years & 3 & 30 & 4 & 40 & 3 & 30 & 2 & 20 \\
16 -20 years & 2 & 20 & 0 & 0 & 3 & 30 & 4 & 40 \\
Above 20 years & 3 & 30 & 4 & 40 & 2 & 20 & 5 & 50 \\
Rank of Officers & 4 & 40 & 3 & 30 & 6 & 60 & 3 & 30 \\
HFS & 2 & 20 & 3 & 30 & 1 & 10 & 2 & 20 \\
PFS & 1 & 10 & 0 & 0 & 1 & 10 & 0 & 0 \\
\hline CFS & & & & & & & & \\
\hline
\end{tabular}

NB: HFS = Higher Forest Superintendent, PFS= Principal Forest Superintendent, CFS = Chief Forest Superintendent, $P F O=$ Principal Forest Officer

\subsection{Types of Conflicts that have Occurred in Forest Reserves of the Study Area}

Table 6 shows the types of conflicts that have occurred in forest reserves of the study area. According to the Table $60 \%$ of the respondents (forestry personnel) stated that disputes between forest communities over community boundary is a type of conflict that occurred in Akure forest reserve. Ten percent and $20 \%$ of the respondents (forestry personnel) stated that the type of conflicts that occurred in Oyinmo forest reserve is disputes between forest concessionaires and forest community dwellers and conflict between foresters and forest community dwellers respectively. $30 \%$ and $10 \%$ of the respondents (forestry personnel) stated that the type of conflicts that occurred in Eba Island forest reserve is conflicts between foresters and forest concessionaires and disputes between herdsmen and farmers respectively. In addition $70 \%$ of the respondents (forestry personnel) stated that the type of conflict that occurred in Ipele / Ido ani forest reserve is herdsmen and farmers clash. Rahim [16] noted that the manifestation of conflict behavior starts with disagreement, followed by verbal abuse and interference. It is important to note that the type of conflicts identified is a reflection of their origin i.e. forest reserve. Study .com [17] stated that to understand the different types of conflicts, it is important to remember that the different types of conflict reflect where the conflict originates. It therefore follows that the different types of conflicts identified are so because they originate from the use of forest products in the forest reserves. This is because forest reserves have become sites for conflicts due to the question of control, access to the forest and forest products and claims over the forests. Agbeja and Otesile [4] noted that among other things the types of conflicts found in forest reserves of Ogun state are boundary disputes between contiguous communities, destruction of agricultural produce by nomadic cattle (i.e. herdsmen and farmers conflicts and destruction of economic trees by illegal farmers (Disputes between forest concessionaires and forest community dwellers).

Table6. Types of conflicts that have occurred in forest reserves of the Study area (Forestry Personnel).

\begin{tabular}{|c|c|c|c|c|c|c|c|c|}
\hline \multirow[t]{3}{*}{ Types of conflicts } & \multirow{2}{*}{\multicolumn{2}{|c|}{$\begin{array}{l}\text { Akure forest } \\
\text { reserve }\end{array}$}} & \multirow{2}{*}{\multicolumn{2}{|c|}{$\begin{array}{l}\text { Oyinmo Forest } \\
\text { reserve }\end{array}$}} & \multicolumn{2}{|c|}{ Eba Island } & \multirow{2}{*}{\multicolumn{2}{|c|}{$\begin{array}{l}\text { Ipele Ido ani } \\
\text { Forest reserve }\end{array}$}} \\
\hline & & & & & & $\%$ & & \\
\hline & $\mathrm{N}$ & $\%$ & $\mathrm{~N}$ & $\%$ & & & $\mathrm{~N}$ & $\%$ \\
\hline Disputes over community boundary & 6 & 60 & 5 & 50 & 4 & 40 & 6 & 60 \\
\hline $\begin{array}{l}\text { Disputes between forest concessionaires and } \\
\text { forest community dwellers. }\end{array}$ & 5 & 50 & 1 & 10 & 3 & 30 & 6 & 60 \\
\hline $\begin{array}{l}\text { Conflicts between foresters and forest } \\
\text { community dwellers }\end{array}$ & 4 & 40 & 2 & 20 & 4 & 40 & 5 & 50 \\
\hline $\begin{array}{l}\text { Conflicts between foresters and forest } \\
\text { concessionaires }\end{array}$ & 4 & 40 & 2 & 20 & 3 & 30 & 6 & 60 \\
\hline Disputes between herdsmen and farmers & 7 & 70 & 8 & 80 & 2 & 20 & 7 & 70 \\
\hline
\end{tabular}

Source: Field Survey, 2018. NB: There are multiple choices by respondents 


\subsection{Causes of Conflicts in Forest Reserves of the Study Area}

Table 7 shows that $70 \%$ and $80 \%$ of the respondents (forestry personnel) stated that the conflicts that have occurred in Akure forest reserve were caused by boundary encroachment and illegal felling and theft respectively. In Oyinmo forest reserve, $60 \%$ and $70 \%$ of the respondents (forestry personnel) stated that the conflicts that have occurred in the forest reserve were caused by illegal burning and destruction of agricultural crops and tree seedlings (i.e. herdsmen invasion) respectively. In Ipele/ Idoani forest reserve $60 \%$ of the respondents (forestry personnel) stated that the conflicts that have occurred in the forest reserve were caused by corruption. From the foregoing it follows that illegal felling and theft, herdsmen invasion and boundary encroachment are the major causes of conflicts in forest reserves of the study area. This is because many people disregard forest law that stipulates that permit must be obtained before a tree can be felled. They carry out illegal felling and theft of felled logs. This often results into conflicts between timber contractors and forest community dwellers. Timber contractors are the rightful concessionaire. They have obtained and paid for the permit. However it should be noted that some timber contractors cause conflicts because they failed to renew their permit. They are involved in illegal felling and felling of under girth trees thereby causing conflicts between them and forestry officials. Oso and Agbeja [18] noted that timber contractors in Ondo state, Nigeria are involved in illegal felling, felling of undersized logs, non-renewal of property hammer and failure to produce log certificate.

Herdsmen invasion usually results in the conflicts between them and the farmers. This is a major cause of conflicts in forest reserves of the study area because majority of forest community dwellers are farmers. Farming is their major livelihood as such destruction of their farm crops is usually frowned at and most of the time it results into serious physical combat. The third identified major cause of conflicts in forest reserves of the study area is boundary encroachment. This is responsible for the conflicts that occurred between forest communities and between farmers from different communities. In their desperate efforts to increase their farm size some farmers and other community dwellers encroached into the contiguous land. This often results into serious conflicts between the concerned farmers and sometimes the conflicts escalates into inter community conflict. Forest community dwellers because majority of them are farmers are always on the look for fertile land. This makes them to sometimes encroached into someone else land resulting into conflicts. Agbeja and Otesile [4] noted that the major causes of conflicts in forest reserves in Ogun State, Nigeria are illegal felling of trees, destruction of agricultural crops and economic tree saplings, boundary disputes between contiguous communities and encroachment into forest lands.

Table 8 shows that $75 \%$ and $80 \%$ of the respondents (forest community dwellers) in Akure forest reserve stated that conflicts that have occurred in the reserve were caused by boundary encroachment and illegal felling and theft respectively. This shows that forest community dwellers also concur with what forestry personnel said. 63\% and 70\% of the respondents ((forest community dwellers) stated that the cause of conflicts in Oyinmo forest reserve is illegal burning and destruction of agricultural crops and tree seedlings (herdsmen invasion) respectively. This also conforms very closely with what forestry personnel respondents said. In Eba Island forest reserve 50\% of the respondents (forest community dwellers) stated that the causes of conflicts that have occurred in the reserve were caused by corruption. This has to do with corruption on the part of forestry officials. Some of the forest community dwellers accused some forestry officials of not following forest laws. They collect money from some community dwellers to carry out illegal felling or to steal felled logs. This often results into conflicts between forestry officials and some timber contractors. Bishnu [10] noted that corruption and bad governance among other factors are part of the major causes of resource conflict in Nepal.

Chi-square test $(\mathrm{p}<0.05)$ shows that there is significant association between educational qualification, economic class and age of forest community dwellers and their involvement in causing conflicts in the study area (Table 9 and hypotheses , 2 and 3). The implication of this is that those that acquire formal education are not likely to be involved in fights or quarrels over the use of forest products. The knowledge they acquired through education has enlightened them and polishes them. As such they are not likely to be involved in any form of fighting's, quarrels or conflicts. If they are aggrieved they will take legal action. Adedayo [19] noted that education is very important to the behavior of an individual. It affects the way people think reason and communicate with other people. Education has formative effect on the mind, character or physical ability of an individual [20]. 
Evaluation of Occurrence and Resolution of Conflicts in and around Forest Reserves in Ondo State, Nigeria

In the same vein economic class of forest community dwellers has a significant association with their involvement in conflicts in forest reserves of the study area. The reason for this is because those in the high economic class and some of the middle class (i.e. the rich) usually can take legal action to get justice in law court. They can also afford to hire the service of a legal practitioner to ensure they get justice. However those in the low economic class (i.e. the poor) cannot afford to hire the service of a lawyer and as such they do not go to court. Instead they get involved in serious fightings and quarrels any time they feel their right is being trampled upon. As such the poor tend to be more involved in conflicts more than the rich.

Chi-square test result also shows that age of respondents in the study area has a significant association with their involvement in causing conflicts. The implication of this is that the younger people (i.e. the youth) are likely to be involved in conflicts in forest reserves while the older people are not likely to be involved in conflicts in forest reserves. The reason for this is because the youth are full of energy and vigour. Many of them do not have the money and the patient to obtain permit to fell logs. Many of them therefore engage in illegal felling of logs and sometimes theft of logs. Attempt to prevent them from carrying out illegal felling or to arrest them sometimes results into fighting's, abuse or armed attack. Balogun and Adedayo [21] identified fighting, armed attack, abuse and destruction of properties as common conflicts that occurred in forest reserves of Ondo State as a result of restrictions of people to forest reserve. Adetula [5] also noted that in recent times youngsters have constituted themselves into militant groups to resist and even harass uniformed staff whose mandate is to protect the forest estate. This has resulted into many casualties including injuries and death.

Table7. Causes of conflicts in Forest Reserves of the Study area as Identified by Forestry Personnel.

\begin{tabular}{|c|c|c|c|c|c|c|c|c|}
\hline \multirow[t]{3}{*}{ Causes of conflicts } & \multirow{2}{*}{\multicolumn{2}{|c|}{$\begin{array}{l}\text { Akure forest } \\
\text { reserve }\end{array}$}} & \multirow{2}{*}{\multicolumn{2}{|c|}{$\begin{array}{l}\text { Oyinmo Forest } \\
\text { reserve }\end{array}$}} & \multicolumn{2}{|c|}{ Eba Island } & \multirow{3}{*}{\multicolumn{2}{|c|}{$\begin{array}{l}\text { Ipele Ido- } \\
\text { ani Forest } \\
\text { reserve }\end{array}$}} \\
\hline & & & & & & $\%$ & & \\
\hline & & & & & & & & $\%$ \\
\hline Boundary encroachment & 7 & 70 & 6 & 60 & 5 & 50 & 5 & 50 \\
\hline Destruction of cash crops & 5 & 50 & 1 & 10 & 2 & 40 & 3 & 30 \\
\hline Illegal felling and theft & 8 & 80 & 2 & 20 & 4 & 40 & 6 & 60 \\
\hline Illegal burning & 4 & 40 & 6 & 60 & 2 & 20 & 6 & 60 \\
\hline $\begin{array}{l}\text { Destruction of agric. crops and tree } \\
\text { seedlings (herdsmen invasion) }\end{array}$ & 8 & 80 & 7 & 70 & 3 & 30 & 7 & 70 \\
\hline Corruption & 3 & 30 & 4 & 40 & 3 & 30 & 4 & 40 \\
\hline
\end{tabular}

Source: Field Survey, 2018. NB: There is multiple choices by respondents

Table8. Causes of conflicts in Forest Reserves of the Study area as Identified by Forest Community dwellers.

\begin{tabular}{|c|c|c|c|c|c|c|c|c|}
\hline \multirow[t]{3}{*}{ Causes of conflicts } & \multicolumn{2}{|c|}{$\begin{array}{l}\text { Akure forest } \\
\text { reserve }\end{array}$} & \multicolumn{2}{|c|}{$\begin{array}{l}\text { Oyinmo Forest } \\
\text { reserve }\end{array}$} & \multicolumn{2}{|c|}{ Eba Island } & \multirow{2}{*}{\multicolumn{2}{|c|}{$\begin{array}{c}\text { Ipele Ido ani } \\
\text { Forest } \\
\text { reserve }\end{array}$}} \\
\hline & \multirow[t]{2}{*}{$\mathrm{N}$} & \multirow[t]{2}{*}{$\%$} & \multirow[t]{2}{*}{$\mathrm{N}$} & \multirow[t]{2}{*}{$\%$} & \multirow[t]{2}{*}{$\mathrm{N}$} & \multirow[t]{2}{*}{$\%$} & & \\
\hline & & & & & & & $\mathrm{N}$ & $\%$ \\
\hline Boundary encroachment & 60 & 75 & 52 & 65 & 40 & 50 & 46 & 58 \\
\hline Destruction of cash crops & 54 & 68 & 38 & 48 & 35 & 44 & 32 & 40 \\
\hline Illegal felling and theft & 64 & 80 & 40 & 50 & 45 & 56 & 65 & 81 \\
\hline Illegal burning & 42 & 53 & 50 & 63 & 32 & 40 & 68 & 85 \\
\hline $\begin{array}{l}\text { Destruction of agric. crops and tree } \\
\text { seedlings (herdsmen invasion) }\end{array}$ & 46 & 58 & 56 & 70 & 38 & 48 & 64 & 80 \\
\hline Corruption & 50 & 63 & 60 & 75 & 40 & 50 & 62 & 78 \\
\hline
\end{tabular}

Source: Field Survey, 2018. NB: There is multiple choice by respondents

\subsection{Resolution of Conflicts in Forest Reserves of the Study Area}

Table 10 shows how conflicts are resolved in forest reserves in the study area. $40 \%$ and $30 \%$ of the respondents (forestry personnel) in Akure and Oyinmo forest reserves respectively stated that conflicts are resolved through boundary verification/ demarcation. These are conflicts that are caused by boundary encroachment. Verification of boundaries and making clear cut boundary demarcation has been used to resolve this conflict. Usually committee made up of forestry officials from the State Forestry Department and prominent members of the community are used for boundary demarcation and verification. $80 \%$ and $70 \%$ of the respondents (forestry personnel) in Oyinmo and Ipele/ Ido-ani 
Evaluation of Occurrence and Resolution of Conflicts in and around Forest Reserves in Ondo State, Nigeria

forest reserves respectively stated that conflicts are resolved in these forest reserves through forestry stakeholders meetings with community leaders. Forestry officials usually arrange meetings between major forestry stakeholders and community leaders. This has always being helping to resolve conflicts. It is part of local community customs and norms to respect community leaders. These include Obas, chiefs and religious leaders. Their words and judgments are always obeyed by the people and this has been helping to maintain peace in local communities. Adedayo [22] noted that despite several attempts aimed at relegating traditions and customs to the background in the country, they remain an enduring part of rural heritage and they play crucial roles in the maintenance of peace, progress and management of common properties in rural communities. It is interesting to note that rural dwellers in the country hold tenaciously to their traditions beliefs and customs. Through this, conflicts are resolved and peace is maintained in local communities in Nigeria.

Chi-square test $(p<0.05)$ shows that the involvement of foresters in conflict resolution in forest reserves of the study area is dependent on their working experience in the study area (hypothesis 4 of Table 9). The implication of this is that it is only forestry officials that have acquired more than 10 years working experience that are mostly involved in conflict resolution in forest reserves of the study area. The reason for this is because such officials are believed to have acquired enough experience to know what to do, so as to resolve conflicts. In addition, forestry officials that have been working for long periods are known by many forestry stakeholders and community leaders. It is therefore easy for such officials to call for meetings of forestry stakeholders with community leaders in order to resolve conflicts.

$40 \%$ of the respondents (forestry personnel) stated that conflicts are resolved in Eba island forest reserve through strict punishment of trouble makers (Table 10). It should be noted that when trouble makers are arrested and punished promptly, it serve as deterrent to other potential trouble makers. As such it helps to reduce conflicts to the barest minimum.

$50 \%$ of the respondents (forestry personnel) stated that conflicts are resolved in Ipele / Ido-ani forest reserve through orientation of forest community dwellers and other major forestry stakeholders (Table 10). This orientation is achieved through both formal and informal means. Formal orientation is carried out through workshops organized by the State Forestry Department with timber contractors, saw millers and other forestry stakeholders. Informal orientation is carried out when forestry officials meet with local community dwellers one -on - one. They carry out informal discussion through which they enlighten the local people on the need to avoid conflicts and how peace can bring about the development of a community. Adebayo [23] noted that peace brings development and progress to the society. Without peace, development is not possible As a matter of fact businesses as well as all forms of livelihoods can only thrive well under a peaceful atmosphere.

Table 10 further showed that $60 \%$ of the respondents (forestry personnel) stated that conflicts are resolved in Akure forest reserve through mediation/ dialogue. This is a situation whereby foresters intervene in disputes between two parties. The intention is to nip in the bud disputes between two warring groups or individuals. Forsyth [24] noted that a mediator is a person who attempts to resolve conflict between two group members by intervening in the conflict. Put simply, the mediator can be thought of as a disinterested guide directs the disputants through the process of developing a solution to a disagreement [24].

Table9. Chi-square values of hypotheses tested

\begin{tabular}{|c|c|c|c|c|}
\hline Hypotheses & $\chi 2$ cal. & $\chi 2$ Tab & \multicolumn{2}{c|}{ RF } \\
\hline $\begin{array}{c}\text { 1. Association b/w educational } \\
\text { qualification of forest community } \\
\text { dwellers and their involvement in } \\
\text { causing conflicts in forest reserves of the } \\
\text { study area }\end{array}$ & 67.94 & 32.67 & 21 & significant \\
\hline $\begin{array}{c}\text { 2. Association b/w economic class of } \\
\text { forest community dwellers and their } \\
\text { involvement in causing conflicts in } \\
\text { forest reserves of the study area }\end{array}$ & 28.14 & 23.70 & 14 & significant \\
\hline
\end{tabular}


Evaluation of Occurrence and Resolution of Conflicts in and around Forest Reserves in Ondo State, Nigeria

\begin{tabular}{|c|c|c|c|c|}
\hline $\begin{array}{c}\text { 3. Association b/w age of forest } \\
\text { community dwellers and their } \\
\text { involvement in causing conflicts in } \\
\text { forest reserves of the study area. }\end{array}$ & 86.32 & 40.10 & 28 & significant \\
\hline $\begin{array}{c}\text { Association b/w working experience of } \\
\text { foresters and their involvement in } \\
\text { conflict resolution in forest reserves of } \\
\text { the study area }\end{array}$ & 46.3 & 40.10 & 28 & significant \\
\hline
\end{tabular}

Table10. How conflicts are resolved in Forest reserves of the Study area (Forestry Personnel

\begin{tabular}{|c|c|c|c|c|c|c|c|c|}
\hline \multirow[t]{2}{*}{ How conflicts are resolved } & \multicolumn{2}{|c|}{$\begin{array}{l}\text { Akure forest } \\
\text { reserve }\end{array}$} & \multicolumn{2}{|c|}{$\begin{array}{l}\text { Oyinmo Forest } \\
\text { reserve }\end{array}$} & \multicolumn{2}{|c|}{ Eba Island } & \multirow{2}{*}{\multicolumn{2}{|c|}{$\begin{array}{l}\text { Ipele Ido } \\
\text { ani Forest } \\
\text { reserve }\end{array}$}} \\
\hline & $\mathrm{N}$ & $\%$ & $\mathrm{~N}$ & $\%$ & $\mathrm{~N}$ & $\%$ & & \\
\hline Boundary Verification/ demarcation & 4 & 40 & 3 & 30 & 1 & 10 & 2 & 20 \\
\hline $\begin{array}{l}\text { Forestry stakeholders meeting with } \\
\text { community leaders }\end{array}$ & 7 & 70 & 8 & 80 & 6 & 60 & 7 & 70 \\
\hline Strict Punishment of trouble makers & 6 & 60 & 5 & 50 & 4 & 40 & 4 & 40 \\
\hline $\begin{array}{l}\text { Orientation of forest community dwellers } \\
\text { and other major forestry stakeholders }\end{array}$ & 5 & 50 & 6 & 60 & 4 & 40 & 5 & 50 \\
\hline Mediation/ dialogue & 6 & 60 & 4 & 40 & 5 & 50 & 6 & 60 \\
\hline
\end{tabular}

Source: Field Survey, 2018. NB: There is multiple choice by respondents

\section{CONCLUSION}

This study has shown that types of conflicts that have occurred in forest reserves of the study area include disputes between forest communities over community boundary, disputes between forest concessionaires and forest community dwellers, conflict between foresters and forest community dwellers, conflicts between foresters and forest concessionaires and disputes between herdsmen and farmers. The study also revealed that conflicts that have occurred in forest reserves of the study area were caused by boundary encroachment, illegal felling and theft, illegal burning, herdsmen invasion and corruption. The study further showed that conflicts are resolved in forest reserves in the study area through boundary verification/ demarcation, forestry stakeholders meetings with community leaders, orientation of forest community dwellers and other major forestry stakeholders and through mediation/ dialogue.

\section{REFERENCES}

[1] Schmid, A. (1998). Thesaurus and glossary of early warning and conflict prevention Terms. (Abridged version). London. Retrieved Sep.9, 2008 from www.womenwarpeace.org/issues/prevention/docs/thes.pdf.

[2] Shah,A.(2010).ConflictsinAfric:Introduction.http://www.globalissues.org/issue/83/conflicts-in-africa. Accessed on 25- 01- 2018.

[3] Walker, G. B. and Daniels, S. E. (1997). Foundations of natural resource conflict: Conflict theory and public policy. In: Solberg B, Miina S, editors. Conflict Management and Public Participation in Land Management. EFI [European Forest Institute] Proceedings 14.Joensuu, Finland: EFI, pp. 13-36.

[4] Agbeja, B. O. and Otesile, A. A. (2011). Conflicts and forest land use:: A case study of forest reserves in Ogun State, Nigeria. Forests and Forest Product Journal $461-74$.

[5] Adetula, T. (2008): Challenges of sustainable forest management in Ondo State: Community Based Forest Management System as a panacea. In: Research for Development in Forestry, Forest products and Natural Resources Management (eds. Onyekwelu, J.C., Adekunle, V.A.J. and Oke, D.O) Proceedings of the First National Conference of the Forests and Forest Products Society, Federal University of Technology, Akure, Nigeria. $16^{\text {th }}-18^{\text {th }}$ April 2008. Pp.242-252.

[6] Enabor, E. E. (1981). Problem of Forest Resources Management in Nigeria. Agric. research Bulletin. Faculty of agriculture and Forestry, University of Ibadan, Ibadan, Nigeria. 2 (20 15.

[7] Marfo, E., (2009). Security of Tenure and community benefits in collaborative forest management in Ghana, A country Report, Accra, Ghana.

[8] Barrett, C. B., Reardon, T., \& Webb, P. (2001). Nonfarm income diversification and household livelihood strategies in rural Africa: concepts, dynamics, and policy implications. Food policy, 26 (4), 315-331.

[9] Marfo, E., 2006. Powerful relations: The role of actor-empowerment in the management of natural resource conflict. PhD thesis Wageningen University. 
Evaluation of Occurrence and Resolution of Conflicts in and around Forest Reserves in Ondo State, Nigeria

[10] Bishnu, R. U. (2004). Resource Conflicts and Conflict Resolution in Nepal, Mountain Research and Development 24(1), https://doi.org/10.1659/0276-4741(2004)024[0060: $\quad$ RCACRI]2.0.CO;2

[11] Woolnough, T; J. C. F. Ugalde and A. Bradley (2018). Forests for peace: the role of forests in conflict reduction. UN - RED programme. www.un-redd.org 23 May 2018.

[12] FAO (2012). Conflict Management in Forestry. www.fao.org/forestry/conflict/en/ Accessed on 19-12 2018.

[13] Zachrisson, A. and Lindah, K. B. (2013). Conflict resolution through collaboration: Preconditions and limitations in forest and nature conservation controversies. Forest Policy and Economics Journal. Volume 33, August 2013, Pages 39-46.

[14] Rahim, M. A. (2002) Toward a Theory of Managing Organizational Conflict International Journal of Conflict Management 13(3) DOI: 10.2139/ssrn.437684

[15] Keay, R.W. (1959): An Outline of Nigerian Vegetation. $3^{\text {rd }}$ Edition. Federal Ministry of Information, Printing Division, Lagos, pp, 461.

[16] Rahim, M. A. (2010). Managing Conflict in Organizations. Transaction Publishers. October, 2010 ISBN 978-1-4128-1456-0. Retrieved 11 January, 2018.

[17] Study .com (2019). Conflict: Definition, Sources and Types. https:// study.com. Accessed on $3^{\text {rd }}$ January, 2019.

[18] Oso, A. O. and Agbeja, B.O. (2016): Impact of Involvement of Stakeholders in Forest Policy implementation in Southwestern Nigeria. In: B.O. Agbeja, A.C. Adetogun, O.R. Adejoba and I.O. Osunsina (Eds.) Proceedings of the 1st Commonwealth Forestry Association (CFA) Conference, Nigeria Chapter held at Forestry Research Institute of Nigeria (FRIN), Jericho, Ibadan, Nigeria. 10 - 12 October, 2016. Pp. $315-320$.

[19] Adedayo, A. G. (2015): Assessment of the relationship between Government Forest Officers and Forest Fringe Communities Dwellers Living around Forest Reserves in Ondo State, Nigeria. The Nigeria Journal of Forestry.45 (1) 1-8.

[20] Wikipedia (2011): The free Encyclopedia on Education. http://www.en.wikipedia.org cited on11th August, 2011.

[21] Balogun, L. B. and Adedayo, A. G. (2015): Evaluation of restriction and conflicts in and around Akure and Oluwa forest reserves in Ondo State, Nigeria. In: Babalola, F.B and Amusa, T (editors) proceedings of Nigeria Tropical Biology Association (NTBA) $5^{\text {th }}$ Annual Biodiversity conference, FUTA, 19-20 ${ }^{\mathrm{TH}}$ may 2015.pp 277-284.

[22] Adedayo, A.G. (2010): Women tenurial rights to forest resources utilization and its impact on their livelihood in North Central Nigeria. Unpublished PhD Thesis of the Department of Forestry and Wood Technology, Federal University of Technology, Akure, Nigeria.Pp.134.

[23] Adedayo, A. G. (2018). Harnessing the potentials of NTFPs for National Development in Nigeria. Journal of Experimental Agriculture International. 24 (4) pp. 1 -10. July, 2018.

[24] Forsyth, D. R. (2006). Conflict. In D. R. Forsyth (Ed.), Group Dynamics (5th ed., pp. 388-389).

\section{AUTHOR'S BIOGRAPHY}

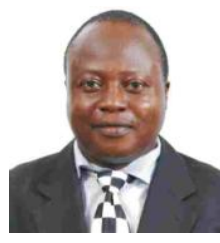

Dr. Adedayo, is an Associate Professor in the Department of Forestry and Wood Technology, Federal University of Technology, Akure, Nigeria. Areas of Research Interest are Gender and Forest Resources Utilization, Forest Governance, Forestry and Rural Poverty reduction, Forestry and Conflict resolution, Forest Policy, Law and Administration

Citation: Adedayo, A. G., (2019). "Evaluation of Occurrence and Resolution of Conflicts in and Around Forest Reserves in Ondo State, Nigeria” International Journal of Research Studies in Agricultural Sciences (IJRSAS), 5(3), pp. 8-18, http://dx.doi.org/10.20431/2454-6224.0503002

Copyright: (c) 2019 Authors. This is an open-access article distributed under the terms of the Creative Commons Attribution License, which permits unrestricted use, distribution, and reproduction in any medium, provided the original author and source are credited. 